Relations industrielles

Industrial Relations

\title{
Manpower Planning in a Free Society, by Richard A. Lester, Princeton University Press, Published by Saunders of Toronto Ltd, 1966, 22 pages.
}

\section{Jean Sexton}

Volume 22, numéro 3, 1967

URI : https://id.erudit.org/iderudit/027823ar

DOI : https://doi.org/10.7202/027823ar

Aller au sommaire du numéro

Éditeur(s)

Département des relations industrielles de l'Université Laval

ISSN

0034-379X (imprimé)

1703-8138 (numérique)

Découvrir la revue

Citer ce compte rendu

Sexton, J. (1967). Compte rendu de [Manpower Planning in a Free Society, by Richard A. Lester, Princeton University Press, Published by Saunders of

Toronto Ltd, 1966, 22 pages.] Relations industrielles / Industrial Relations, 22(3), 453-453. https://doi.org/10.7202/027823ar

Tous droits réservés @ Département des relations industrielles de l'Université Laval, 1967
Ce document est protégé par la loi sur le droit d'auteur. L'utilisation des services d’Érudit (y compris la reproduction) est assujettie à sa politique d'utilisation que vous pouvez consulter en ligne.

https://apropos.erudit.org/fr/usagers/politique-dutilisation/ 
1.-Labor Relations is illustrated with ten carrefully selected arbitration coses.

2. - This book is a depth study of the behovioral phases of labor relations.

3.-It emphasizes the vital issues of collective bargoining.

4.-Labor Relations considers the impact of technology, growth of white-collar employment and worker motivation.

5.--Labor Relations contains a detailed mock negotiation problem

In concluding, let us say that this book is a very interesting study of the labor relotions reality and a practical and comprehensive approach to the negotiation and administration of today's labor-management issues.

\section{Jean SEXTON}

Manpower Planning in a Free Society, by Richard A. Lester, Princeton University Press, Published by Saunders of Toronto Ltd, 1966, 22 pages.

While in the fifties the main preoccupation in industrial relations was unionmanagement relations, today the spotlight has shifted to another areo which tended until recently to be neglected, manpower policy.

The central theme of this book is that the hand of government can and should be used more constructively to facilitate effective utilization of manpower. The role of government should not be to control on direct manpower but rather to moke it easier for individuals to choose careers, to prepare themselves adequately and to change jobs

The author analyzes the need for manpower planning, the nature of such planning and the ways that it could improve the functionning of our mixed economy.

Mr. Lester's recommandations include:

1.-exponding reseorch and analysis to give more depth to the Annual Manpower Reports of the President.

2.-extending the functions of the Federal State Employment Service including the establishment of a national cleoring center for high tolent manpower. 3.-improving programs of information and training to enlarge opportunities at all levels, enabling men and women to realize more fully their potentiol earning power and economic contribution.

In addition to these recommandations this book urges that more stress be placed on knowledge-generating research and on the distribution of useful information about monpower needs and opportunities. Manpower Planing in a Free Society sets forth a pattern of thought and a program of action.

\section{Jean SEXTON}

Information and Economic Progress, Howard R. Bowen and Garth L. Mangum, Editors, 170 p. $\$ 4.95$, Clothbound $/ \$ 1.95$ poper, Prentice-Hall Inc., 1967.

The editors of this volume are Dr. Howard $R$. Bowen, president of the University of lowa and Garth L. Mangum. Dr. Bowen was chairman and Dr. Mangum executive secretary of the National Commission on Technology, Automation, and Economic Progress, whose report was filed in 1966. The Commission was appointed by President Johnson pursuant to an act of the Congress of the United States. Its distinguished membership ambraced leaders in management, labor and ocodemic and public life.

The reviewer had occasion to offer a critiaue of the findings of the Commission in Personnel Journal, April, 1966 issue.

The book contains a condensation of the text of the Commission's report, together with selections from the six published volumes of supplementary studies which contain much source material for the report.

Since the report, itself, is divided into various chapters and considers more than 40 topics, only highlight references can be made here. Serious students of the industrial scene will from a careful examination of its content and the Commission views on these various subjects.

Some of the proposals of the Commission have never been advanced by any official bodies in the United States. These included a guaranteed minimum maintenance of income provision, reverse tox benefits, the ossumption of a governmental obligation to employ the hard core jobless, and the great expenditure of public moneys for the accomplishment of these social purposes. 